\title{
MEYVE VE SEBZELERİN KURUTULMASINDA ÖN İŞLEM OLARAK VURGULU ELEKTRIKK ALAN KULLANIMI
}

\author{
Yasemin Çiftci*, Mustafa Fincan \\ Erciyes Üniversitesi, Mühendislik Fakültesi, Gıda Mühendisliği Bölümü, Kayseri, Türkiye
}

Geliş / Received: 11.02.2021; Kabul / Accepted: 06.05.2021; Online bask1 / Published online: 21.05.2021

Çiftci, Y., Fincan, M. (2021). Meyve ve sebzelerin kurutulmasında ön işlem olarak vurgulu elektrik alan kullanımı. GIDA (2021) 46 (4) 830-847 doi: 10.15237/gida. GD21036.

Ciftci, Y., Fincan, M. (2021). The use of pulsed electric field as a pre-treatment for drying of fruits and vegetables. GID $A$ (2021) 46 (4) 830-847 doi: 10.15237/gida. GD21036.

\section{ÖZ}

Meyve ve sebzelerin geleneksel yöntemler ile kurutulmasında, uygulanan kurutma sıcaklığının ve süresinin derecesi nihai ürünün kalite ve maliyetine önemli derecede etkide bulunmaktadır. Uygulanan yüksek sıcaklık ve uzun kuruma süreleri genellikle istenmeyen değişimleri tetikleyerek, ürünün kalite öğelerinde azalmalara yol açmakta ve enerij sarfiyatını artırmaktadır. Vurgulu elektrik alan tekniği, kurutmadaki bu olumsuzlukları azaltma potansiyeline sahip son yıllarda ortaya çıan alternatif tekniklerden birisi olarak bilinmektedir. Şu ana kadar yapılan çalışmaların birçoğunda meyve sebzelerin bu teknik ile kurutulmasında kalite öğelerinin daha fazla korunduğu ve enerji sarfiyatının azaltılabileceği bildirilmiştir. Bu derleme kapsamında, vurgulu elektrik alan uygulamasının meyve sebzelerin kuruma davranışı ve kalite özellikleri üzerindeki etkileri değerlendirilmiştir.

Anahtar kelimeler: Vurgulu elektrik alan, meyveler, sebzeler, kurutma

\section{THE USE OF PULSED ELECTRIC FIELD AS A PRE-TREATMENT FOR DRYING OF FRUITS AND VEGETABLES}

\begin{abstract}
In drying of fruits and vegetables using traditional methods, the degree of drying temperature and time applied significantly affect the quality and cost of the final product. The high temperature and long drying periods generally trigger unwanted changes, causing a decrease in the quality attributes of product and an increase in energy expenditure. Pulsed electric field technique is known to be one of the alternative techniques that has emerged in recent years, which has the potential to reduce these drawbacks in drying. In most of the studies conducted so far, it has been reported that with this technique the quality attributes are more protected and the energy consumption can be reduced in the drying of fruits and vegetables. Within the scope of this review, the effects of pulsed electric field application on the drying behavior and quality characteristics of fruits and vegetables were evaluated.
\end{abstract} Keywords: Pulsed electric field, fruits, vegetables, drying

\footnotetext{
*Yazışmalardan sorumlu yazar / Corresponding author

(t): yasemenciftcii@gmail.com

Yasemin Çiftci; ORCID no: 0000-0001-9934-0723

Mustafa Fincan; ORCID no: 0000-0002-9394-6449
}

(ग): (+90) 5443920369

圆: (+90) 3524375784 


\section{GİRİ̧̧}

Meyve ve sebzelerin günümüzde kullanılan birçok geleneksel kurutma yöntemleri ile kurutulmasinda, kurutma yöntemine, uygulanan sıcaklık seviyesi ve süresine bağlı olarak çeşitli kalite kayıpları ortaya çıkmakta, bazen de yüksek enerji sarfiyat1 nedeniyle ürünün maliyetini yükseltmektedir. Buna karşın tüketiciler, besin öğeleri yüksek oranda korunmuş, sağlık üzerinde olumlu etkileri olan ve ekonomik kazancı artıran kurutulmuş gida ürünlerini talep etmektedir. Birçok çalışma (Dziki, 2020; Lammerskitten vd., 2019; Ostermeier vd., 2020; Radojčin vd., 2021; Wu vd., 2020; Yu vd., 2018) meyve ve sebzelerin kurutulmasinda vurgulu elektrik alan (PEF) tekniğinin olumlu etkileri olduğunu göstermektedir. PEF, kurutma işlemlerinde kalite ve enerji kayıplarını azaltmak için umut verici bir teknik olarak karşımıza çıkmaktadır (Kempkes ve Simpson, 2018; Llavata vd., 2019; Mousakhaniganjeh vd., 2021; Zhang vd., 2020).

Yüksek su aktivitesine sahip olan çiğ meyve ve sebzeler mekanik hasarlara, mikrobiyal bozulmalara ve çevresel koşullara karşı oldukça duyarlı olması nedeniyle bozulmaya elverişli bir yapıdadır. Kurutulmuş ürünlerde dayanım büyük ölçüde suyun uzaklaştırılması ile gerçekleşmektedir. Belirli bir su aktivitesine kadar uzaklaştırılan su sonrası mikrobiyal ve enzimatik aktivite sinırlanmakta, arzu edilmeyen fiziksel ve kimyasal değişiklikler en aza indirgenerek raf ömrü uzun gida ürünleri elde edilmektedir (Mayor ve Sereno, 2004). Kurutma sicaklığına bağlı olarak su, bitkisel dokudan uzaklaşırken çeşitli yapısal engeller ile karşlaşmaktadır. Büyük oranda hücre içi bölgede bulunun suyun çıkışına öncelikle hücre zarlar1, sonrasinda hücre duvar1 ve katman kalınlığ1 direnç göstermektedir (Khan vd., 2018). Kurutma boyunca hücre su kaybedip, büzülerek plazmolize uğramakta ve böylece hücre zarlarının direnci önemli oranda azalmaktadır (Ando vd., 2014; Lewicki ve Pawlak, 2003).

Meyve ve sebzelerin kurutulması geleneksel olarak vakumlu kurutma, güneşte kurutma, sıcak hava ile kurutma, dondurarak kurutma, akışkan yataklı kurutma ve tepsili kurutma gibi yöntemler ile gerçekleştirilmektedir. Geleneksel teknikler ile kurutulan meyve ve sebzelerin çoğunlukla 1s1 uygulamasına bağlı olması kurutma sırasinda oluşan bazı kalite sorunlarını beraberinde getirmektedir. Kurutulmuş meyve ve sebzeler ile ilgili başlıca kalite problemleri olan renk, doku, aroma ve besin maddelerini etkileyen değişiklikler gıda ürününü tüketiciler için kabul edilemez hale getirmektedir (Onwude vd., 2017; Sagar ve Kumar, 2010). Yapılan çeşitli araştırmalarda geleneksel yöntemlerle kurutulan havuç, zencefil, kivi, elma, altın çilek, nar, mango, portakal, hünnap ve domates gibi birçok meyve ve sebzede fenolik madde ve karotenoid içeriklerinin azaldığ1 rapor edilmiştir (Bozkir, 2020; Demiray ve Tulek, 2017; Ghafoor vd., 2020; Grabowska ve Marcin, 2021; Hamid vd., 2020; Izli vd., 2017a, 2017b; Nawirska-Olszańska vd., 2017; Sehrawat vd., 2018; Smith vd., 2018; Wojdyło vd., 2019). Baz1 çalışmalarda sıcak havayla kurutulan pancarda, betanin içeriğinin azaldığı belirtilmiştir (Kerr ve Varner, 2020; Liu vd., 2020). Sicak havayla kurutulan muz, guava, hünnap, yaban mersini, vişne, çilek, kızılcık meyveleri, yeşil biber, dolmalık biber ve brokolide $C$ vitamini kayıpları rapor edilmiştir (Leiton-Ramírez vd., 2020; Nemzer vd., 2018; Rybak vd., 2020; Szadzińska vd., 2017; Takougnadi vd., 2020; Wang vd., 2020; $\mathrm{Xu}$ vd., 2020). Kurutma yöntemleri arasında 1sıl işlem içeren uygulamalarda kırmızı biber, karadut ve terebinth meyvesinde büyük oranda renk değişimleri tespit edilmiştir (Abbaspour-gilandeh vd., 2020; Chen vd., 2017; Koç, 2020). Mierzwa ve Pawłowski (2017) yaptıkları çalışmada sıcak hava ile kurutulan patatesin görünüşünde fark edilebilir bir deformasyon gözlemlemişlerdir. Sıcak hava, mikrodalga ve kız1lötesi kurutma yöntemleriyle kurutulan kırmızı biberler duyusal olarak değerlendirildiğinde, panelistler tarafından en az tercih edilen örneklerin sıcak hava ile kurutulmuş olduğu belirtilmiştir (Guclu vd., 2021).

Tüm bu olumsuz sonuçlar neticesinde meyve ve sebzelerin kuruma özelliklerini iyileştirmek için geleneksel kurutma teknikleriyle kombine halde kurutma işlemi öncesi ön işlemler uygulanmaktadır. Çoğu ön işlemlerin amacı doku yapısını bozup, böylece suyun çıkışını kolaylaştırmaktır. Su çıkısıının kolaylaşması, 
kurumanın daha düşük sıcaklık ve kısa süre kullanılmana imkân tanıyarak, beraberinde ortaya çıkan kalite kayıplarını azaltmaktadır. Son zamanlarda bitki hücre zarlarının geçirgenliğini artırarak meyve ve sebzelerin kurutulmasını kolaylaştıran aynı zamanda ürün kalitesinin koruyan ve isısal olmayan PEF ön işlemi dikkat çekmektedir (Huang vd., 2019; Sagar ve Kumar, 2010). PEF destekli kurutma, daha kısa kuruma süresi, düşük enerji tüketimi ve yüksek kalitede ürünler elde edilmesi gibi avantajları ile öne çıkan bir teknoloji olarak bilinmektedir.

\section{Vurgulu Elektrik Alan (PEF) Tekniği}

Vurgulu elektrik alan (PEF), elektrotlar arasina yerleştirilen hücre sistemlerine kesikli aralıklarda DC (doğru akım) voltaj uygulamasıdır. Uygulamanın bilenen en önemli etkisi, elektriksel alana maruz birakilan hücrede önemli bir 1s1 artışına yol açmadan hücre zarlarında kalıcı veya geçici gözenekler (porlar) oluşturmasıdır. Bu şekilde gözenek oluşturma işlemi elektroporasyon veya elektropermeabilizasyon olarak adlandırılmaktadır. Por oluşum mekanizması tam olarak aydınlatılmamış olmasına rağmen, buna dair Zimmermann tarafindan (Zimmermann, 1986) sunulan dielektrik parçalanma teorisi en çok kabul görenler arasında yer almaktadır. Bu teoriye göre, hücre dişarıdan bir elektrik alana maruz bırakıldığında, dielektrik hücre zarının iç ve diş yüzeylerinde zit yüklü iyonlar polarize olarak transmembran potansiyel (TMP)'in artışına yol açmaktadır. TMP'indeki artş̧a paralel iyonlar hücre zarında gittikçe artan bir basınç, sıkıştırma kuvveti meydana getirir ve nihayet TMP'i 1 Volt değerine ulaştığında hücre zarında gözenekler açılmaya başlamaktadır. Bu kritik seviyenin üzerinde elektrik alan uygulamasının sürdürülmesi halinde, hücre zarında kalıcı mekanik hasar oluşması tersinir olmayan elektroporasyon, kritik seviyeye kadar uygulanması halinde gözeneklerin açllıp kapanması ise tersinir elektroporasyon olarak adlandırılmaktadır (Kotnik vd., 2019; Ramaswamy ve Ramachandran, 2017; Zimmermann, 1986).

Gözeneklerin veya elektroporasyonun özellikleri diğer bazı şartlardan da etkilenmektedir. Özellikle, uygulanan elektrik alan kuvveti, vurgu şekli, vurgu genişliği, vurgu sayısı ve vurgu frekansının büyüklüğü belirleyici olmaktadır. Elektrik alan kuvvetinin büyüklüğü elektroporasyonda en önemli bir parametre iken diğer elektriksel değişkenlerin etkisi farklilık göstermektedir. Vurgu genişliği ve sayısındaki artışın hücre zarında bozunumu artırdığ1 gösterilirken, vurgu frekansının por oluşumu hakkındaki rolü üzerine sonuçlar değişmektedir (Kandušer ve Miklavčič, 2008). En yaygin kullanilan vurgu şekilleri üstel azalan ve kare dalga biçimidir. Kare dalga şeklinin, üstel azalana göre daha az 1sı artışına yol açtığı bilinmektedir. Elektriksel parametrelerin yanında, hücrelerin içinde bulunduğu sıcaklık, elektriksel iletkenlik ve hücre büyüklügü gibi bazı ortam özelliklerinin de elektroporasyon özellikleri üzerine etkileri bulunmaktadır. Aynı şartlarda elektrik alan parametrelerine maruz birakilan hipotonik ortamdaki hücreler, izotonik bir ortamdan daha düşük voltajda geçirgen hale gelmektedir (Rols ve Teissie, 1990). Önemli oranda lipitlerden oluşan hücre zarı yüksek sıcaklığa maruz bırakıldığında daha akışkan hale geldiğinden, daha düşük elektrik alan şiddetinde geçirgen hale gelmektedir (Kak1 vd., 2014; Rols ve Teissie, 1990). Elektriksel iletkenlik değerinin artması, uygulama esnasinda 1 si artş̧ını da indüklediğinden, hücre zar1 deformasyonunda ısının etkisi ayrıca ortaya çıkmaktadır. Yapılan bazı çalışmalarda, ortam elektriksel iletkenlik değeri azaldıkça hücre parçalanma oranın arttı̆̆ gözlemlenmiştir (Hülsheger vd., 1981; Silve vd., 2016). Hücre büyüklüğü arttıkça indüklenen membran potansiyeli arttı̆̆ından hücre boyutu büyük olan hücreler küçük olan hücrelere göre elektrik alanın verdiği hasara daha duyarlı hale gelmektedir (Gaylor vd, 1988). Hücre zar1 por geçirgenliğini sağlamak için gerekli olan elektrik alan kuvveti mikroorganizmalar (hücre boyutu 1$10 \mu \mathrm{m})$ için $12-20 \mathrm{kV} / \mathrm{cm}$ aralığında iken bitki hücrelerinde (hücre boyutu 40-200 $\mu \mathrm{m}$ ) 1-2 $\mathrm{kV} / \mathrm{cm}$ 'dir (Soliva-fortuny vd., 2009).

Elektroporasyon geçmişten bu zamana biyoteknolojide gen aktarımında bilinen ve uygulanan bir tekniktir. Bununla beraber, tekniğin bitkisel hücrelerin, mikroorganizmaların ve tümörlerin inaktivasyonu gibi diğer alanlardaki potansiyeli üzerine çalışmalar son yıllarda artarak 
devam etmektedir (Ariza-gracia vd., 2020; Emanuel vd., 2020; Maor vd., 2021; Rubin vd., 2018; Shabbir vd., 2020; Xu vd., 2018; Zhao vd., 2021). Meyve ve sebzelerin işlenmesi söz konusu olduğunda, tersinir olmayan elektroporasyon tekniğinin özellikle kütle transferini içeren kurutma ve ekstraksiyon proseslerini kolaylaştıric1 potansiyeli üzerinde durulmaktadır (Yarmush vd., 2014). Geleneksel kurutmada hücre zarlarını bozundurup, kütle transferini artırmak için kurutma sicaklığını en az $55-65{ }^{\circ} \mathrm{C}$ civarına çıkarmak şart iken, PEF ön işlemi sonrası bu şart değildir (Eshtiaghi ve Knorr, 2002). Çünkü, PEF ile hücre zarları bozunan dokudan kütle transferi daha düşük sıcaklıklarda da hızlanmakta veya kurutma daha düşük sıcaklıklarda da gerçekleştirilebilmektedir. Bundan başka, herhangi bir PEF uygulamasının indüklediği doku bozunum oran1, kuruma prosesini direkt olarak etkilemektedir. Diğer bir deyişle, dokuda bozunan hücre sayısı ne kadar artarsa, buharlaşan su miktarı da buna paralel artmakta, kuruma kolaylaşmaktadır. Dolayısıyla, PEF ile ortaya çıkan doku bozunum veya elektroporasyon seviyesinin belirlenmesi kuruma prosesini değerlendirmede kritik bir öneme sahip olmaktadir.

\section{Doku Bozunum Oranın Belirlenmesi}

Doku bozunum oranın $\left(\mathrm{Z}_{\mathrm{p}}\right)$ belirlenmesinde yaygin olarak kullanılan yöntem, dokuların elektriksel özelliklerine dayanmaktadır. Sağlam bir dokunun elektriksel iletkenliği frekans değerine bağlıdır. $\alpha$-frekans bölgesinde (1-100 kHz) hücre zarları yalıtkan özelliklerini büyük ölçüde korurken akım (iletkenlik) ağırlıklı olarak hücre dışı bölgedeki iyonların ifadesidir. Buna karşın, $\beta$ frekans bölgesinde (0.1-100 MHz), hücre zarlar1 yalıtkan özelliklerini frekans arttıkça kaybetmeye başlamaktadır (Maxwell-Wagner etkisi), bununla birlikte hücre içi iyonlar da iletkenliğe dahil olmakta, dolayısıyla ölçülen iletkenlik hem hücre içi hem de hücre dışı iyonların bir ifadesi haline gelmektedir. Sağlam dokunun iletkenliği bu şekilde frekansa bağlı iken, hücreleri tam olarak bozunmuş dokunun iletkenliği farklı davranış göstermektedir. Bozunmuş hücre zarları bariyer özelliklerini kaybettiğinden ve buna bağlı olarak iyonca zengin hücre içi içeriğin hücre dışına yayılmasından, iletkenlik her iki frekans bölgesinde de sabit kalmaya meyil etmektedir (Şekil 1). Buna göre, ölçüm yeterince yüksek frekansta yapıldığında sağlam doku ve tam parçalanmış doku elektriksel iletkenlikleri birbirine yakın olmaktadır. Hücreleri sağlam, kısmen parçalanmış ve tam parçalanmış bitki dokusunun frekans artırımına karşı davranışları aşağıdaki Şekil 1'de (Knorr ve Angersbach, 1998) şematize edilmektedir (Foster, 2008).

$\mathrm{Bu}$ olgulardan yararlanılarak, herhangi bir işlem (PEF veya diğer) sonrası ortaya çıkan doku parçalanma oranı $\left(Z_{\mathrm{p}}\right)$ 'nın tahminine yönelik farklı yöntemler geliştirilmiştir. En basit yaklaşımda, $Z_{\mathrm{p}}$ $\alpha$-frekans alanındaki elektriksel iletkenliğin $\beta$ frekans alanina oranından tahmin edilmektedir. Bundan başka, Angersbach vd. (1999), dokuların frekans tepkisini kullanan bir doku parçalanma indeksi $Z_{\mathrm{p}}$ tanımlamaktadır.

$Z_{p}=\frac{\left(\begin{array}{c}\sigma_{h}^{i} \\ \sigma_{h}^{t}\end{array}\right) \sigma_{l}^{t}-\sigma_{l}^{i}}{\sigma_{h}^{i}-\sigma_{l}^{i}}$

(Denklem 1)

$\sigma_{l}^{t}$ ve $\sigma_{l}^{i}$ sırasıyla düşük frekansta $(1-5 \mathrm{kHz})$ işlem görmüş ve işlem görmemiş (sağlam) dokunun, $\sigma_{h}^{t}$ ve $\sigma_{h}^{i}$ ise sirasiyla yüksek frekansta $(3-50 \mathrm{MHz})$ işlem görmüş ve işlem görmemiş dokunun iletkenliğidir. Buna göre, sağlam doku için $\mathrm{Z}_{\mathrm{p}} \approx 0$, tam parçalanmış doku için $Z_{\mathrm{p}} \approx 1$ olmaktadır.

Bundan başka, $\alpha$-frekans alanındaki elektriksel iletkenliği göz önüne alarak $Z_{p}$ tahmini içeren diğer yöntemler de geliştirilmiştir. Bu yöntemlerde herhangi bir işlem (PEF veya diğer) sonrası hasıl olan elektriksel iletkenlik dondurup-çözme veya 1sıl işlem gibi tam doku parçalamayı sağlayan bir işlemden sonra hasıl olan iletkenliğe bölünerek, $Z_{p}$ tahmini yapılmaktadır. Örneğin dokunun su içeresinde PEF işlemine maruz bırakıldığında tanımlanan bir endeks de:

$Z_{p}=\frac{\sigma-\sigma_{s}}{\sigma_{m a k s}-\sigma_{s}}$

(Denklem 2)

$\sigma, \sigma_{\text {maks }}$ ve $\sigma_{s}$ sirasıyla işlem gören, tam parçalanmış numunenin ve dokuyu çevreleyen suyun elektriksel iletkenliğidir. Fincan (2015) ve 
Lebovka vd. (2002) tarafindan tanımlanan diğer bir endeks de:

$Z_{p}=\frac{\sigma-\sigma_{i}}{\sigma_{d}-\sigma_{i}}$

(Denklem 3)

$\sigma$, işlem görmüş dokunun $\alpha$-frekans alanındaki elektriksel iletkenlik, "i" ve " $\mathrm{d}$ " alt indisi ise sırasıyla sağlam ve tamamen parçalanmış dokunun iletkenliğini ifade etmektedir. Sağlam hücre için $\mathrm{Z}_{\mathrm{p}} \approx 0$, tamamen parçalanmış hücre için $\mathrm{Z}_{\mathrm{p}} \approx 1$ olmaktadır.
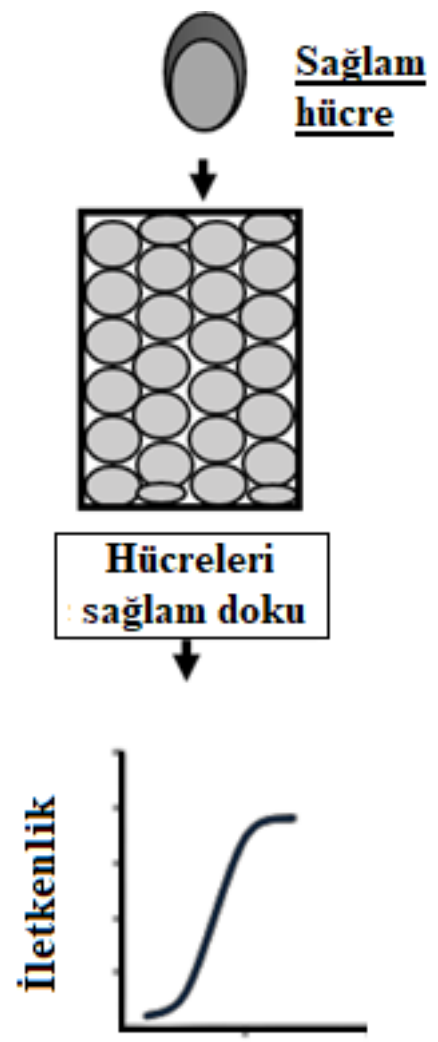

$\log \mathbf{f}[\mathrm{Hz}]$

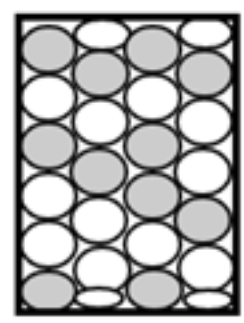

Hücreleri kısmen parçalanmıș doku
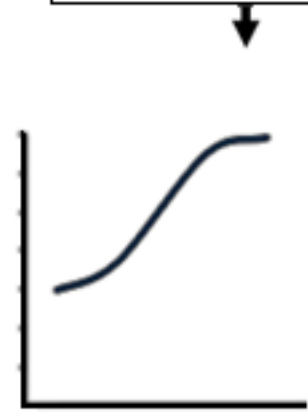

$\log \mathbf{f}[\mathrm{Hz}]$
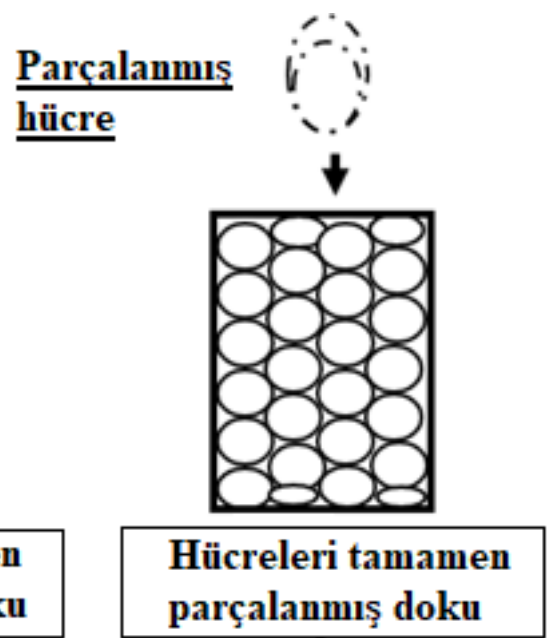

$\downarrow$

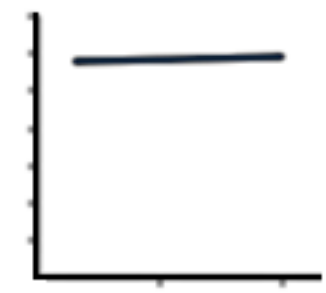

$\log \mathbf{f}[\mathrm{Hz}]$

Şekil 1. Hücreleri sağlam, kısmen parçalanmış ve tam parçalanmış bitki dokusunun 1 kHz-50 MHz ölçüm frekansı aralığında tipik frekans-iletkenlik spektrumları (Knorr ve Angersbach, 1998)

\section{PEF Ön İşlemi ile Kurutma}

Sağlam bitkisel dokuda \%90'a varan oranlarda bulunan su, hücre içi bölgede hücre zarları tarafindan hapsedilmekte ve dişarıya çıkışı engellenmektedir. Destek görevi üstlenen hücre duvarı da su çıkışına engel teşkil eden bir bariyer olmasına rağmen, su çıkışına direnç gösteren temel bariyer hücre zarıdır. İşte PEF ile kurutma prosesinin iyileştirilmesi potansiyeli temelde PEF'in hücre zarlarındaki bozunum etkisine dayanmaktadır. Bununla birlikte, PEF'in bu etkisinin kurutma sıcaklığının $55{ }^{\circ} \mathrm{C}$ altındaki sıcaklıklarda gerçekleștirildiğinde daha geçerli olduğu göz ardı edilmemelidir. Bu sıcaklık seviyesi üzerinde hücre zarlar1 1s1 etkisiyle bozunmaya (plazmoliz) başladıklarından, PEF ile önceden hücre bozunumu önemini kaybetmeye başlamaktadır (Eshtiaghi ve Knorr, 2002). Diğer taraftan, $\quad 55 \quad{ }^{\circ} \mathrm{C}$ altındaki sicaklıklarda gerçekleştirilen kurutma prosesinde, bozunan hücre zarları suyun çıkışına izin vererek, kurutmanın hızlanmasına yol açmaktadır. Buna örnek olarak Alam vd. (2018) yaptı̆̆1 çalışma incelendiğinde, $50^{\circ} \mathrm{C}$ 'de sicak hava ile kurutulan 
havuçlarda PEF ön işlemi kuruma süresini \%13 azaltırken, $70{ }^{\circ} \mathrm{C}$ 'de kurutulan örneklerde kuruma süresinde bir azalma gözlenmemiştir. PEF’in düşük sicaklıklarda kisa süren kurutmaya elveren bu potansiyeli yapılan bazı ön çalşsmalarda ele alınmış, istenmeyen birçok reaksiyonları azalttığ1 ve ekonomik açıdan maliyeti düşürdüğü gösterilmiştir. PEF'in tüm bu olumlu yanlarına rağmen, meyve ve sebzelerdeki kurutma rolü yeterince aydınlatılmamıştır. Şu ana kadar yapılan çalışmalarda, bazı meyve ve sebzelerin elektroporasyonunda farklı PEF parametreleri kullanılmış bunun yanı sıra farklı kurutma sıcaklıkları denenmiştir. Çeşitli meyve ve sebzelerin PEF yardımlı kurutma işleminde kullanılan deneysel şartların ve bulguların bir özeti Çizelge 1'de gösterilmektedir.

Çizelge 1. Farklı çalışmalardan PEF destekli meyve-sebze kurutulmasının bir özeti

\begin{tabular}{llll}
\hline Örnek & PEF İşlem Koşulları & Etkileri & Referanslar \\
\hline Soğan & Üstel azalan monopolar vurgu, & $45^{\circ} \mathrm{C}$ kuruma sıcaklı̆̆ında $1.07 \mathrm{kV} / \mathrm{cm}$ elektrik & (Ostermeier vd., \\
& $0.36-1.07 \mathrm{kV} / \mathrm{cm}$ elektrik alan & alan kuvveti ve $4 \mathrm{~kJ} / \mathrm{kg}$ spesifik enerji girişinde & $2018)$ \\
& kuvveti, $40 \mu$ s vurgu genişliği, 2 & kuruma süresinde $\% 30$ düşüş gözlenmiştir. & \\
& Elektrik alan kuvvetinin artmasıyla birlikte \\
& & hücre parçalanma oranı da artmıştır. 1.07 \\
& $\mathrm{kV} / \mathrm{cm}$ elektrik alan kuvvetinde hücre \\
& parçalanma oranı $\mathrm{Z}_{\mathrm{p}}=0.47 \pm 0.07$ olarak \\
& bulunmuştur.
\end{tabular}

Erik Unipolar kare dalga vurgu, 1, 2 En yüksek hücre parçalanma oranı $\left(\mathrm{Z}_{\mathrm{p}}=0.572\right)$ ve $3 \mathrm{kV} / \mathrm{cm}$ elektrik alan ve nem difüzyon katsayısı $\left(0.27 \times 10^{-9} \mathrm{~m}^{2} / \mathrm{s}^{\prime}\right.$ den kuvveti, 30 vurgu

Elma Monopolar yakın-dikdörtgen vurgu, $0.66-2.34 \mathrm{kV} / \mathrm{cm}, 8-92$ vurgu, vurgular aras1 $25 \mu \mathrm{s}$

Elma Monopolar dikdörtgen şeklinde vurgu, 1-2 $\mathrm{kV} / \mathrm{cm}$, vurgular aras1 $900 \mathrm{~ms}, 10-60$ vurgu, vurgu genişliği $90 \mu \mathrm{s}$

Kay1s1 $\quad 0.625$ ve $1.25 \mathrm{kV} / \mathrm{cm}, 30$ ve 60 s, $100 \mathrm{~Hz}$, vurgu genişliği $20 \mu \mathrm{s}$

Nane $0.147,0.294$ ve $1.43 \mathrm{kV} / \mathrm{cm}$ elektrik alan kuvveti, 2, 10, 100 ve $0.2 \mathrm{~ms}$ vurgu genişliği, 1, 5, ve $10 \mathrm{~s}$ vurgu aralığ1, $10-1485$ aralığında vurgu sayısı $\left.16.47 \times 10^{-9} \mathrm{~m}^{2} / \mathrm{s}^{\prime} \mathrm{ye}\right) 3 \mathrm{kV} / \mathrm{cm}$ elektrik alan kuvvetinde gözlenmiştir. Yüksek hücre parçalanması kuruma oranını artırmış, kuruma süresini kısaltmıştır.

(Rahaman vd., 2019)

Proses değişkenleri $1.25 \mathrm{kV} / \mathrm{cm}$ elektrik alan kuvveti, 50 vurgu sayss ve $80{ }^{\circ} \mathrm{C}$ işlem sıcaklığında optimize edilmiştir. Hücre parçalanma oranı $\mathrm{Zp}=0.90$ olarak bulunmuştur.

PEF işlemi, kuruma süresini 0.86 sa azaltmıştır. Enerji tüketimi $1.5 \mathrm{kV} / \mathrm{cm}$ 'de 35 vurgu sayısında \%24.74 azalmıştır. Etkin difüzyon katsayis1 $2.40 \times 10^{-8} \mathrm{~m}^{2} / \mathrm{s}$ 'den $3.10 \times 10^{-8} \mathrm{~m}^{2} / \mathrm{s}^{\prime}$ ye yükselmiştir.

Elektrik alan kuvveti 0.625 'den $1.25 \mathrm{kV} / \mathrm{cm}$ 'ye ve işlem süresi $30 \mathrm{~s}$ 'den $60 \mathrm{~s}$ 'ye ç1kması sonucu kuruma oranında artış görülmüştür.

$1.43 \mathrm{kV} / \mathrm{cm}, \quad 0.2$ vurgu genişliğinde ve $0.294 \mathrm{kV} / \mathrm{cm}, 100 \mathrm{~ms}$ vurgu genişliği şartlarında vurgu sayısı arttıkça kuruma sürelerinin kısaldığı görülmüştür. Yüksek elektrik alanında (1. 43 $\mathrm{kV} / \mathrm{cm}), 160 \mathrm{x} 2 \mathrm{~ms}, 0.1 \mathrm{~Hz}$ ve $10 \mathrm{~s}$ vurgu aralığ şartlarında uygulandığında hücre parçalanma oranı $Z_{p}=81.30 \pm 4.84$ olarak bulunmuştur.
(Chauhan vd., 2018)

(Wu ve Zhang, 2019)

(Huang vd., 2019)

(Aldemir, 2019) 
Çizelge 1. devam

\begin{tabular}{|c|c|c|}
\hline Örnek & PEF İşlem Koşulları & Etkileri \\
\hline $\begin{array}{l}\text { Kirmız1 } \\
\text { dolmalık } \\
\text { biber }\end{array}$ & $\begin{array}{l}1.0 \mathrm{kV} / \mathrm{cm} \text { elektrik alan } \\
\text { kuvveti, } 20-200 \text { üstel azalan } \\
\text { vurgu, } 143 \mu \text { s vurgu genişliği, } 1 \\
\text { Hz frekans }\end{array}$ & $\begin{array}{l}\text { PEF ile işlem görmüş örneklerin rehidrasyon } \\
\text { kapasitesi } \% 50 \text { artmiştır. Hücre parçalanma } \\
\text { oranı } 0.6-0.8 \text { arasında rapor edilmiştir. }\end{array}$ \\
\hline Fesleğen & $\begin{array}{l}65 \text { monopolar karesel vurgu, } \\
650 \mathrm{~V} / \mathrm{cm} \text { elektrik alan } \\
\text { kuvveti, } 150 \mu \mathrm{s} \text { vurgu süresi, } \\
\text { vurgular aras } 760 \mu \mathrm{s}\end{array}$ & $\begin{array}{l}\text { PEF ön işlemi kuruma süresini, sıcak hava ile } \\
\text { kurutulan örnekte } \% 57 \text {, vakum ile kurutulan } \\
\text { örnekte } \% 33 \text { ve dondurularak kurutulan } \\
\text { örnekte } \% 25 \text { oranında azaltmıştır. }\end{array}$ \\
\hline Patates & $\begin{array}{l}600 \mathrm{~V} / \mathrm{cm} \text { elektrik alan } \\
\text { kuvveti, } 100 \text { monopolar vurgu } \\
\text { vurgu süresi } 100 \mu \mathrm{s} \text {, vurgular } \\
\text { arasi süre } 10 \mathrm{~ms}\end{array}$ & $\begin{array}{l}\text { PEF işlemi, etkin nem difüzyonunu artırarak ön } \\
\text { kurutma işlemini ve nem kaybının hızlanmasına } \\
\text { yol açması ile kızartma prosesinin kısalmasını } \\
\text { sağlamıștır. }\end{array}$ \\
\hline
\end{tabular}

Referanslar

Yaban $\quad 2 \mathrm{kV} / \mathrm{cm}, 2 \mu$ s vurgu genişliği, $\quad 75,60$ ve $45^{\circ} \mathrm{C}$ ’lerde vakumla kurutma öncesi mersini 200 vurgu, 96 ms işlem süresi

PEF ön ișlemi, kuruma süresinde sirasıyla 6 sa'ten 4 sa'e, 10 sa'ten 7 sa'e ve 70 sa'ten 40 sa'e düşüş göstermiştir.

Mango $1.07 \mathrm{kV} / \mathrm{cm}$ elektrik alan PEF ön işlemi vakumla kurutulmuş örneklerin kuvveti, monopolar üstel rehidrasyon yeteneğini PEF1 ve PEF2 için azalan vurgu, vurgu süresi 40 sırasıyla 3.14'den (işlem görmemiş) 3.11'e ve $\mu$ s, vurgular arası $0.5 \mathrm{~s}, 2 \mathrm{~Hz}, 2.52$ 'e, sıcak hava ile kurutulmuş örneklerin ise spesifik enerji girişi PEF1 sırasıyla $\% 2$ ve $\% 15$ oranında azaltmıştır.

$(1 \mathrm{~kJ} / \mathrm{kg}) ; \mathrm{PEF} 2(3 \mathrm{~kJ} / \mathrm{kg})$

Çilek 100 ve $200 \mathrm{~V} / \mathrm{cm}, 10 \mu$ s vurgu Ozmotik dehidrasyon ile kombine halde kullanılan PEF ön ișlemi her iki meyvede de su kaybını \%21.6 oranında artırmıştır. Her iki (Telfser ve Galindo, 2019)

(Liu vd., 2018a) ve kivi genişliği, $100 \mathrm{~Hz}$ frekans, $10 \mathrm{~s}$ işlem süresi

meyvede de antioksidan kapasite ve aktiviteyi artırmıştır.

Ispanak $3 \mathrm{kV} / \mathrm{cm}$ elektrik alan kuvveti, $1 \mu \mathrm{s}$ vurgu genişliği, vurgu sayısı 1, işlem süresi $15 \mathrm{dak}$,

Kurutma öncesi PEF ön işlemi kuruma süresini 1.8 kat kısaltmıştır.

PEF ön işlemi görmüş çilekler işlem görmemişlere kıyasla şekli ve hacmi korunmuş, daha yüksek görsel kalite sergilemiştir. Daha homojen bir kuruma sağlanmıştır.

Kurutma öncesi, ozmotik dehidrasyon ve PEF uygulamas1 (vurgu sayis1 750'den 7500'e yükseldikçe), su kaybını artırmıştır. $2.8 \mathrm{kV} / \mathrm{cm}$, $15 \mu$ s vurgu genişliği ve $20 \mathrm{~Hz}$ frekans şartlarında hücre parçalanma indeksi $\left(Z_{p}\right), 750$, 1500 ve 7500 vurgu sayilarında sirasiyla 0.13 , 0.20 ve 0.38 olarak bulunmuştur.

Yamada vd., 2020)

(Lammerskitten vd., 2020)

(Tylewicz vd., 2020)

(Lammerskitten, vd., 2020)

(Dermesonlouo glou vd., 2018) 
Çizelge 1. devam

\begin{tabular}{|c|c|c|c|}
\hline Örnek & PEF İşlem Koşulları & Etkileri & Referanslar \\
\hline Safran & $\begin{array}{l}2 \mathrm{kV} / \mathrm{cm} \text { elektrik alan kuvveti, } \\
50 \text { dikdörtgen şeklinde vurgu, } \\
20 \mu \text { s vurgu genişliği, } 1 \mathrm{~ms} \\
\text { toplam işlem süresi, } 50 \mathrm{~Hz} \\
\text { frekans }\end{array}$ & $\begin{array}{l}\text { Kurutma öncesi PEF ön işlemi, safran aroması } \\
\text { ve renk gücünde sırasılyla } \% 177 \text { ve } \% 40 \text { artış } \\
\text { göstermiştir. }\end{array}$ & (Neri vd., 2021) \\
\hline Havuç & $\begin{array}{l}0.6 \mathrm{kV} / \mathrm{cm} \text {, monopolar } 10 \\
\text { vurgu, } 100 \mu \mathrm{s} \text { vurgu süresi, } \\
\text { vurgular arasi } 10 \mathrm{~ms}\end{array}$ & $\begin{array}{l}\text { PEF ön işlemi, } 25-90{ }^{\circ} C^{\prime} \text { de kuruma süresini } \\
\text { \%33-55 oranında azaltmıştır. } \beta \text {-karoten kayb1 } \\
\text { ve renk değişimi işlem görmemiş örneklere } \\
\text { kıyasla daha az olduğu görülmüştür. }\end{array}$ & $\begin{array}{l}\text { (C. Liu vd., } \\
\text { 2020) }\end{array}$ \\
\hline Patates & $\begin{array}{l}600 \mathrm{~V} / \mathrm{cm} \text { elektrik alan } \\
\text { kuvveti, } 100 \text { monopolar vurgu, } \\
100 \mu \mathrm{s} \text { vurgu süresi, vurgular } \\
\text { aras } 10 \mathrm{~ms}\end{array}$ & $\begin{array}{l}\text { PEF ön işlemi, kuruma süresini } \% 22-27 \\
\text { oranında azaltmiştır. }\end{array}$ & (Liu vd., 2018b) \\
\hline
\end{tabular}

Ostermeier ve arkadaşları (2018), PEF ön işleminin sıcak hava ile kurutulan taze soğan üzerine etkisini incelemişlerdir. Soğana farklı PEF parametreleri $(\mathrm{W}=0.2-20.0 \mathrm{~kJ} / \mathrm{kg}$ spesifik enerji, $\mathrm{E}=0.36-1.07 \mathrm{kV} / \mathrm{cm})$ uygulanmış, ardından 45 , 60 ve $75{ }^{\circ} \mathrm{C}$ sicakliklarda sicak hava ile kurutulmuştur. Farklı elektrik alan kuvvetlerinde $(0.36 \mathrm{kV} / \mathrm{cm}, 0.71 \mathrm{kV} / \mathrm{cm}$ ve $1.07 \mathrm{kV} / \mathrm{cm})$ ve değişen spesifik enerjilerde hücre parçalanma oranları incelenmiştir. Hücre parçalanması en fazla, $1.07 \mathrm{kV} / \mathrm{cm}$ elektrik alan kuvveti ve $2-16$ $\mathrm{kJ} / \mathrm{kg}$ spesifik enerji girişi aralığında görülmüştür. $1.07 \mathrm{kV} / \mathrm{cm}$ elektrik alan kuvvetinde 1,4 ve 16 $\mathrm{kJ} / \mathrm{kg}$ spesifik enerji değerlerinde soğanın 60 ${ }^{\circ} \mathrm{C}$ 'de kuruma davranış1 işlem görmemiş örnekler ile karşılaştırılmıştır. Bunun sonucunda, PEF ön işlemi görmemiş soğan örneklerinde 300 dakikada istenilen nem seviyesine ulaşırken işlem görmüş numunelerin kuruma süresinde azalma tespit edilmiştir. $4 \mathrm{~kJ} / \mathrm{kg}$ spesifik enerji ile işlenen örneğin kuruma süresi 300 dakikadan 236 dakikaya \%21.33'lük bir azalma ile en hızlı kuruma sağlamıştır. İşlem görmemiş örneklerle kıyaslandığında PEF ön işlemi ile kuruma süreleri 45,60 ve $75^{\circ} \mathrm{C}$ kurutma sicakliklarında sirasiyla $\% 30, \% 21.4$ ve $\% 6.4$ oranında azalmıştır.

Rahaman ve arkadaşları (2019), eriğe uygulanan PEF ön işlemini kuruma kinetiği, hücre parçalanması, renk ve mikro yapisal özellikleri açısından incelemişlerdir. PEF ön işlemi 1, 2 ve 3 $\mathrm{kV} / \mathrm{cm}$ elektrik alan şiddeti, 30 vurgu sayısı ve 10 -
$90 \mathrm{~kJ} / \mathrm{kg}$ spesifik enerji girişi olacak şekilde gerçekleştirilmiştir. Ardından örnekler $70^{\circ} \mathrm{C}$ 'de sıcak hava firınında kurutulmuştur. PEF'in hücre parçalanmasına etkisi, işlem yoğunluğunun ve özgül enerji tüketiminin artmasıyla artş̧ göstermiştir. $1 \mathrm{kV} / \mathrm{cm}$ elektrik alan kuvvetinde hücre parçalanması 0.147 iken 2 ve $3 \mathrm{kV} / \mathrm{cm}$ 'de sirasiyla 0.463 ve 0.572 'ye yükselmiştir. Hücre parçalanması, kuruma oranı ve nem kaybının artırmasına yardımcı olmuştur. Kuruma oranı, PEF yoğunluğunun artmasıyla birlikte artş̧ göstermiş, kuruma süresinin kısalmasina yol açmışır. PEF ön işlemi görmemiş örneğe $\left(0.27 \times 10^{-9} \mathrm{~m}^{2} / \mathrm{s}\right)$ kiyasla nem difüzyon katsayıs 1 , 2 ve $3 \mathrm{kV} / \mathrm{cm}^{\prime}$ de sirasiyla $11.7 \times 10^{-9} \mathrm{~m}^{2} / \mathrm{s}$, $12.15 \times 10^{-9} \mathrm{~m}^{2} / \mathrm{s}$ ve $16.47 \times 10^{-9} \mathrm{~m}^{2} / \mathrm{s}$ olarak artmıştır. Elektron mikroskobunda, işlem görmüş örneklerin hücre zarlarında büzülme meydana geldiği görülmüştür. Kurutma işleminden sonra işlem görmemiş örneklere kıyasla PEF ön işlemi görmüş örneklerin açıklık değeri $\left(L^{*}\right)$ yükselmiştir.

Chauhan vd. (2018), elma dilimlerinin kuruma süresi, enerji girdisi ve hücre parçalanması üzerinde PEF ön işleminin elektrik alan kuvveti (1'den $2 \mathrm{kV} / \mathrm{cm}$ 'ye), vurgu say1s1 (25'ten 75 'e) ve PEF destekli haşlama ön işlemi sırasında suyun sıcaklığının (60'dan $80{ }^{\circ} C^{\circ}$ 'ye) etkisini değerlendirmiştir. Farklı parametrelerde PEF işlemine maruz birakılan elma dilimleri $60^{\circ} \mathrm{C}$ 'de $12 \mathrm{~m} / \mathrm{s}$ hava hızında kurutulmuştur. Enerji girdisinin artmasiyla birlikte hücre zar1 
geçirgenliğinin artmasina bağlı olarak yüksek oranda hücre parçalanması meydana gelmiştir. Zar geçirgenliğinin artması daha fazla suyun uzaklaşması anlamina geldiği için kuruma süresinde azalma gözlemlenmiştir. Uygulanan elektrik alan kuvveti kuruma hızını önemli ölçüde etkilemezken darbe sayısı ve ortam sıcaklığı etkili olmuştur. Bu çalışma sonucunda, iyi kalitede kurutulmuş elma elde etmek için deneysel şartlar, elektrik alan kuvveti $1.25 \mathrm{kV} / \mathrm{cm}$, vurgu sayıs 50 ve su sicaklığ $180^{\circ} \mathrm{C}$ olarak belirlenmiştir.

Wu ve Zhang (2019), elma dokusunun dondurularak kurutma prosesinde PEF ön işleminin etkisini incelemişlerdir. Elma dokusu 1$2 \mathrm{kV} / \mathrm{cm}$ elektrik alan kuvveti, 10-60 vurgu sayıs1, $900 \mathrm{~ms}$ vurgu aralığ $1,90 \mu \mathrm{s}$ vurgu genişliği monopolar dikdörtgen vurgu olacak şekilde PEF işlemine maruz bırakılmıştır. Ön dondurma işlemi $-40{ }^{\circ} \mathrm{C}$ 'de 10 saatte gerçekleștirildikten sonra örnekler $75{ }^{\circ} \mathrm{C}$ 'de kurutulmuştur. Elma dokusunun kuruma karakteristiği incelendiğinde, işlem görmemiş örneklere kıyasla PEF ön işlemi görmüş örneklerin nem değeri önemli oranda azalmıştır. İşlem görmemiş örnek, istenilen nem değerine 230 dakikada ulaşırken PEF ile işlem görmüş örnekler 190 dakikada ulaşmıştır. Ortalama kuruma süresi işlem görmemiş örnekler için 7.50 sa iken PEF ön işlemi görmüş örnekler için 6.64 sa olarak tespit edilmiştir. İşlem görmüş örneklerin enerji tüketimi $\% 24.74$ oranında azalmışır. Enerji verimliliği için en etkili PEF koşulları, $1.5 \mathrm{kV} / \mathrm{cm}$ elektrik alan kuvvetinde 35 vurgu say1s1 olarak belirlenmiştir. PEF sonrası meydana gelen elektroporasyon, membran geçirgenliğini artırmış, kuruma prosesini iyileştirmiştir. PEF ile işlem görmemiş örneklerin rehidrasyon oran1 4.14 iken PEF ön işlemi görmüş $(1 \mathrm{kV} / \mathrm{cm}, 60$ vurgu sayıs1) örneklerin rehidrasyon oranının 7.11 olduğu görülmüştür. Etkin difüzyon katsayis1 (D eff), 2.40x10-8 $\mathrm{m}^{2} / \mathrm{s}^{\prime} \mathrm{den} 3.10 \times 10^{-8}$ $\mathrm{m}^{2} / \mathrm{s}$ 'e yükselmiştir. $D_{\text {eff, }}$ elektrik alan yoğunluğunun ve vurgu sayisının artmasiyla birlikte hızlanma eğilimi göstermiştir.

Huang ve arkadaşları (2019), kayısılara farklı yoğunluklarda PEF ön işlemi uygulamış ardından kuruma oranlarını karşılaştırmıstır. Kontrol olarak: işlem görmemiş, $\% 0.2 \quad \mathrm{Na}_{2} \mathrm{SO}_{3}{ }^{\circ} \mathrm{e}$ daldırılmış işlem görmemiş ve 10 dak $80{ }^{\circ} \mathrm{C}$ 'de 1sıtılmış ardından oda sicaklığında $\% 0.2$ $\mathrm{Na}_{2} \mathrm{SO}_{3}$ 'de 1 saat daldırılmış örnekler kullanılmıştır. PEF işlem koşulları, düşük yoğunluk $(0.65 \mathrm{kV} / \mathrm{cm}, 100 \mathrm{~Hz}, 20 \mu \mathrm{s}, 30 \mathrm{~s}$ işlem süresi), yüksek yoğunluk-kısa süre $(1.25 \mathrm{kV} / \mathrm{cm}$, $100 \mathrm{~Hz}, 20 \mu \mathrm{s}, 30 \mathrm{~s}$ işlem süresi) ve yüksek yoğunluk-uzun süre $(1.25 \mathrm{kV} / \mathrm{cm}, 100 \mathrm{~Hz}, 20 \mu \mathrm{s}$, $60 \mathrm{~s}$ işlem süresi) olarak uygulanmıştır. Sonrasında sicak hava firınında $45^{\circ} \mathrm{C}^{\prime}$ de $1.0 \mathrm{~m} / \mathrm{s}$ hava hizında kurutulmuştur. Elektrik alan kuvveti $0.625^{\prime}$ den $1.25 \mathrm{kV} / \mathrm{cm}$ 'ye ve işlem süresi $30 \mathrm{~s}$ 'den $60 \mathrm{~s}$ 'ye çıkması sonucu kuruma hızında artış görülmüştür. Isıl işlem uygulanmış örneklerin kuruma hızı, düşük yoğunluk ve yüksek yoğunluk-kısa süreli örneklerden daha yüksek, yüksek yoğunluk-uzun süreli örnekten daha düşük bulunmuştur.

Fincan ve Aldemir (2019), nanenin kurutulmasında yüksek ve düşük elektrik alan kuvvetlerinde frekans ve darbe sayısının etkisini işlem görmemiş ve dondurulup çözündürülmüş örnekler ile kiyaslayarak incelemiştir. Yüksek elektrik alan $(1.43 \mathrm{kV} / \mathrm{cm}, 0.2$ vurgu genişliği) ve düşük elektrik alan $(0.294 \mathrm{kV} / \mathrm{cm}, 100 \mathrm{~ms}$ vurgu genişliği) kuvvetlerinde vurgu sayısı arttıkça kuruma sürelerinin kısaldığ1 görülmüsstür. Yüksek elektrik alan kuvvetinde $(1.43 \mathrm{kV} / \mathrm{cm}, 2 \mathrm{~ms}$ vurgu genişliği) frekansın azalma etkisinin yüksek vurgu sayısında (99) önemli olduğu vurgulanmıştır. Frekans değeri azaldıkça kuruma süresi kısalmıştır. En düşük frekans olan $0.1 \mathrm{~Hz}$ 'de kuruma süresi yaklaşı 2.7 saat olarak kaydedilmiştir. Düşük elektrik alan kuvvetinde $(0.147 \mathrm{kV} / \mathrm{cm}, 100 \mathrm{~ms}$ vurgu genişliği) ise frekansın azalmasının önemli bir etkisi olmamış, ancak işlem görmemiş örneklere kıyasla kuruma süresi kısalmıştır.

Fauster vd. (2020) yaptığ1 çalışmada, kırmızı dolmalık biberlerin dondurularak kurutulması sonucu oluşan olumsuz fiziksel özellikleri iyileştirmek amaciyla PEF ön işlemine $(1.0 \mathrm{kV} / \mathrm{cm}$ elektrik alan kuvveti, vurgu genişliği $143 \mu$ s, 20200 arasi vurgu, $1 \mathrm{~Hz}$ frekans ve spesifik enerji girişi $\quad 0.7-6.0 \mathrm{~kJ} / \mathrm{kg}$ olacak şekilde) tabi tutulmuştur. Sonuçlar incelendiğinde, spesifik enerji girişinin artmasıyla birlikte hücre parçalanma indeksi \%30 artmıştır. PEF ön işlemi, 
biberin tekstürel özelliği olan sertlik değerini, işlem görmemiş örneğe kiyasla \%61.1-71.1'e kadar düşürmüştür. PEF ön işlemi görmüş örneklerin rehidrasyon kapasitesinin, işlem görmemiş örneklere kıyasla yüksek olduğu belirtilmiştir.

Telfser ve Galindo (2019), fesleğen yapraklarına (Ocimum basilicum L.) uygulanan PEF ön işleminin farklı kurutma yöntemleri (sıcak hava, vakum ve dondurarak kurutma) üzerine etkilerini incelemişlerdir. Fesleğen yapraklarına, $(650 \mathrm{~V} / \mathrm{cm}$ elektrik alan şiddeti, vurgu süresi $150 \mu$ s, vurgular aras1 $760 \mu$ s ve 65 monopolar karesel vurgu olacak şekilde) PEF ön işlemi uygulanmıstır. Daha sonra ayr1 ayr1 $40{ }^{\circ} \mathrm{C}$ 'de $2 \mathrm{~m} / \mathrm{s}$ hava hizinda, $14 \mathrm{~Pa}$ vakumlu ve $-45{ }^{\circ} \mathrm{C}$ 'de dondurularak kurutulmuştur. Dehidrasyon özellikleri PEF ön işlemi görmemiş örneklerle kıyaslanarak incelendiğinde kurutma metotlarının her birinde nem difüzyonu artmış, kuruma süreleri kısalmıştır. Kuruma süreleri işlem görmemiş örnekler ile kıyaslandığında, sıcak havayla kurutulan örnekte 23.5'ten 10.8 saate, vakum ile kurutulan örnekte 15 'ten 10 saate ve dondurularak kurutulan örnekte 12'den 9 saate düşmüştür. Yani PEF ön işlemi kurutma süresini, sirasiyla $\% 57, \% 33$ ve $\% 25$ oranında azaltmıştır. Taze ve kurutulmuş fesleğen yapraklarının renk özellikleri incelendiğinde, dondurularak kurutulmuş örnekler hariç diğer örneklerin taze yapraklardan daha koyu renkte olduğu görülmüştür. Renkte en fazla koyulaşma, PEF ön işlemi ardından sıcak hava ile kurutulan örneklerde görülmüştür. Fesleğen yapraklarının yeşilliği $\left(a^{*}\right)$, sıcak hava ile kurutulmuş örnekler başta olmak üzere her bir kurutma yönteminde önemli ölçüde azalmıştır.

Liu ve arkadaşları (2018a), PEF ön işlemi ardından sicak hava ile kurutulan patateslerin kızartılması sırasında nem kaybı ve yağ alımı üzerindeki etkilerini incelemişlerdir. Patates dilimleri $25 \mathrm{~mm}$ çap ve $2.5 \mathrm{~mm}$ kalınlığında kesilmiş ardından $600 \mathrm{~V} / \mathrm{cm}$ elektrik alan kuvveti, 100 monopolar vurgu, vurgu süresi $100 \mu$ s ve vurgular aras1 $10 \mathrm{~ms}$ olacak şekilde $\mathrm{PEF}$ uygulanmıştır. Daha sonra örnekler, $50^{\circ}{ }^{\circ}$ 'de 2 $\mathrm{m} / \mathrm{s}$ hava hizinda 500, 1000 ve $2000 \mathrm{~s}$ sicak hava ile kurutulmuş ardından $130{ }^{\circ} \mathrm{C}$ 'de $600 \mathrm{~s}$ kızartılmıstır. Sonuçlar incelendiğinde, PEF işlemi etkin nem difüzyon katsayısını artırarak ön kurutmayı hızlandırmıs, kızartma süresini kısaltmıştır. Kuruma süresine karşı kızartma süresi incelendiğinde, kuruma süresi 500 s'yi aşması halinde kızartma süresi önemli ölçüde azalmıştır. Kurutma süresi $500 \mathrm{~s}$ üzerinde iken kızartmadan sonra yağ alımının, işlenmemiş örnek $(\approx 0.47 \mathrm{~g} / \mathrm{g}$ DM) ile karşılaştırıldığında PEF ile işlenmiş örneklerde $(0.30 \mathrm{~g} / \mathrm{g}$ DM $)$ daha az olduğu görülmüştür.

Yu ve arkadaşları (2017), yaban mersininin sicak hava ve vakumlu olarak kurutulmasında ön işlem olarak uygulanan PEF'in, yaban mersininin besinsel kalite ve kuruma karakteristiği üzerine etkisini incelemiştir. PEF ön işlemi $2 \mathrm{kV} / \mathrm{cm}$ elektrik alan kuvveti, $2 \mu$ s vurgu genişliği, saniyede 200 vurgu ve toplam işlem süresi 96 ms olacak şekilde uygulanmış, ardından vakumlu ve sıcak hava kurutucuda 45,60 ve $75{ }^{\circ} \mathrm{C}$ sicakliklarda kurutulmuştur. Vakumlu kurutma öncesi PEF ön işlemi, kuruma süresini $45^{\circ} \mathrm{C}$ 'de 70 saatten 40 saate, $60^{\circ} \mathrm{C}$ 'de 10 saatten 7 saate ve $75^{\circ} \mathrm{C}$ 'de 6 saatten 4 saate kadar düşürmüştür. Kuruma süresinin kısalması enerji tasarrufuna önemli fayda sağlamışır. $45^{\circ} \mathrm{C}$ 'de sıcak hava ile kurutulmuş örneklerde kuruma oranı hafif hizlanırken, 60 ve $75^{\circ} \mathrm{C}$ 'lerde önemli ölçüde azalma görülmemiştir. $\mathrm{PEF}+$ vakumlu kurutma $\left(75^{\circ} \mathrm{C}\right)$ uygulamasinın, besinsel kayıpları en aza indirmek ve kuruma oranını artırmak için uygun olduğu sonucuna varılmıştır.

Lammerskitten ve arkadaşları (2020), mango dokusuna $1 \mathrm{~kJ} / \mathrm{kg}$ (PEF1) ve $3 \mathrm{~kJ} / \mathrm{kg}$ (PEF2) spesifik enerjiler, $1.07 \mathrm{kV} / \mathrm{cm}$ elektrik alan kuvveti, monopolar üstel azalan vurgu, vurgu süresi $40 \mu \mathrm{s}$, vurgular arası $0.5 \mathrm{~s}$ ve $2 \mathrm{~Hz}$ frekans olacak şekilde PEF işlemi uygulamış, sonrasında vakum ve sicak hava kurutma yöntemi ile $70^{\circ} \mathrm{C}$ 'de kurutmuştur. Sonuçlar incelendiğinde, PEF ön işlemi rehidrasyon kapasitesini vakumlu kurutmada \%21'e, sicak hava kurutmada \%16 'a kadar düşürmüştür. PEF işleminin renk değerleri üzerine etkisi incelendiğinde, PEF1 ön işlemi hem sicak hava hem de vakumlu kurutma işleminde daha koyu kırmızı ve sarı renk değeri göstermiş bunun yanı sıra yüzey parlaklı̆̆ı düşmüştür. PEF 
ön işlemi görmüş örneklerin fenolik madde içerikleri taze örneklere kıyasla $\% 70$ oranında korunmuştur.

Tylewicz ve arkadaşları (2020), kivi ve çilek dokusuna ozmotik dehidrayon (OD) öncesi PEF işlemi uygulanmış (100 ve $200 \mathrm{~V} / \mathrm{cm}, 10 \mu$ s vurgu genişliği, $100 \mathrm{~Hz}$ frekans ve $10 \mathrm{~s}$ işlem süresi), ardından \%40'lık sakkaroz ve trehaloz çözeltisine daldırilarak $25{ }^{\circ} C^{\prime}$ de 120 dak ozmotik dehidrasyon işlemi gerçekleştirilmiştir. Bu işlem, $200 \mathrm{~V} / \mathrm{cm}$ elektrik alan kuvvetinde çilek Örneklerinin antioksidan kapasitesi ve antioksidan aktivitesini sırasıyla $\% 13.6$ ve $\% 11.5$ artırmıs, 100 $\mathrm{V} / \mathrm{cm}$ 'de kivi örneklerinin ise sirasiyla $\% 7$ ve \%15.6 artırmıştır. Renk değerleri incelendiğinde, $200 \mathrm{~V} / \mathrm{cm}$ elektrik alan şiddetindeki PEF ve trehalozlu OD kombinasyonun çilek örneklerinin renginin korunması için en iyi şartları sağladığını rapor etmişlerdir.

Dermesonlouoglou vd. (2018), goji meyvesinin kuruma özelliklerini iyileştirmek için ozmotik dehidrasyon (OD) ve PEF ön işlemi uygulamışlardır. PEF ile ön işlenmiş örnekler (0.9$2.8 \mathrm{kV} / \mathrm{cm}$ elektrik alan kuvveti, $1 \mathrm{kHz}-1 \mathrm{MHz}$ frekans aralığ1, 7500 'e kadar vurgu sayıs1), $55^{\circ} \mathrm{C}$ 'de 180 dak OD’u gerçekleştirilmiştir. Ardından 60 ${ }^{\circ} \mathrm{C}$ 'de 400 dak kurutulmuştur. PEF ile işlem görmüş örnekler, taze + OD ve dondurulmuş çözündürülmüş + OD ile karşılaştırılmıştır. En yoğun PEF şartında $(2.8 \mathrm{kV} / \mathrm{cm}$ ve 7500 vurgu) hücre parçalanma indeksi $\left(\mathrm{Z}_{\mathrm{p}}\right), 0.38$ olarak rapor edilmiştir. PEF ön işlemi, kütle transferini pozitif olarak etkileyerek kurumayı geliştirmiştir.

Yamada ve arkadaşları (2020), 1spanağa kurutma öncesi PEF ön işleminin kuruma hızı üzerindeki etkilerini çalışmışlardır. Ispanak dokusuna PEF işlemi uygulanmış, $(3 \mathrm{kV} / \mathrm{cm}$ elektrik alan kuvveti, $1 \mu$ s vurgu genişliği, 1 vurgu sayısı, işlem süresi 15 dak, toplam enerji girişi $7.1 \mathrm{j} / \mathrm{g}$ olacak şekilde) ardından $50{ }^{\circ} \mathrm{C}$ 'de sicak havayla kurutulmuştur. PEF işlemi uygulanmış örnekler işlem görmemiş örnekler ile karşılaştırıldığında kurutma süresinin 3.5 saatten 2 saate düştüğü rapor edilmiştir. Bu çalışmada, kurutma öncesi PEF ön işleminin yapraklı sebzelerde kurutma hızını iyileştirildiği sonucuna varilmıştır.
Lammerskitten ve arkadaşları (2020), çilek meyvesine PEF uygulamış $(1 \mathrm{kV} / \mathrm{cm}$ elektrik alan kuvveti, vurgular arasi $0.5 \mathrm{~s}$ monopolar üstel azalan vurgu ve vurgu süresi $40 \mu$ s olacak şekilde) ardından dondurarak kurutmuştur. Sonuçlar değerlendirildiğinde, PEF işlemi sonrasında meydana gelen elektroporasyon olayı ile oluşan gözenekler (porlar), işlem görmemiş örnekler ile kıyaslandığında dokuda daha büyük ve homojen bir dağılım sağlamıştır. Böylece kurutulan çilekler daha hacimli bir yapı ve görsel olarak daha iyi bir kalite sergilemiştir. $L^{*} \quad a^{*} \quad b^{*}$ değerleri incelendiğinde, PEF ile muamele edilmiş dokuların daha iyi bir renk kalitesine sahip olduğu görülmüştür.

Neri ve arkadaşları (2021), sıcak havayla kurutma öncesi safranın kalitesi, rengi, tadı, aroması ve fonksiyonel özelliklerinin iyileştirilmesi üzerine PEF'in potansiyelini incelemişlerdir. Safran dokusuna, PEF ön işlemi uygulanmış $(2 \mathrm{kV} / \mathrm{cm}$ elektrik alan kuvveti, 50 dikdörtgen şeklinde vurgu, $20 \mu \mathrm{s}$ vurgu genişliği, $1 \mathrm{~ms}$ toplam işlem süresi, $50 \mathrm{~Hz}$ frekans olacak şekilde) sonra 45 ${ }^{\circ} \mathrm{C}$ 'de 120 dak sicak hava kurutma gerçekleştirilmiştir. Kurutma işlemi safran tat, aroma ve renginde artışlara neden olmuş, özellikle PEF ön işlemi sonrası kurutulan örneklerin aromasinda $\% 177$, renk gücünde $\% 40$ artşs görülmüştür.

Liu ve arkadaşlarının (2020) yaptığı çalışmada, vakum kurutma öncesi PEF ön işleminin havucun kalite özellikleri üzerindeki etkilerini incelemişlerdir. Havuç dilimlerine PEF ön işlemi uygulanmış $(0.6 \mathrm{kV} / \mathrm{cm}$, monopolar 10 vurgu, 100 $\mu$ s vurgu süresi ve vurgular aras $10 \mathrm{~ms}$ olacak şekilde), ardından $25,50,75$ ve $90^{\circ} \mathrm{C}$ sicakliklarda vakumlu olarak kurutulmuştur. Sonuçlar incelendiğinde, sıcaklığın yükselmesiyle birlikte toplam kuruma süresi işlem görmemiş ve PEF ön işlemi görmüş örnekler için sırasıyla 6 saatten 1.5 saate ve 2.7 saatten 1 saate düşmüştür. $\beta$-karoten içeriği ise 25 ve $90{ }^{\circ} \mathrm{C}$ 'de işlem görmemiş örneklerde, sirasiyla $137 \mathrm{mg} / 100 \mathrm{~g}$ ve 131 $\mathrm{mg} / 100 \mathrm{~g}$ iken PEF ön işlemi görmüş örneklerde $170 \mathrm{mg} / 100 \mathrm{~g}$ ve $155 \mathrm{mg} / 100 \mathrm{~g}$ olarak rapor edilmiștir. 
Patates dokusuna PEF ön işlemi uygulanmış (600 $\mathrm{V} / \mathrm{cm}$ elektrik alan kuvveti, 100 monopolar vurgu, $100 \mu \mathrm{s}$ vurgu süresi ve vurgular aras $10 \mathrm{~ms}$ olacak şekilde) ardından farklı sıcaklıklarda (40, 50,60 ve $70^{\circ} \mathrm{C}$ olmak üzere) vakum kurutma işlemi gerçekleştirilmiştir. Kurutma sıcaklı̆̆ının artmasıyla kuruma süresi daha da kısalmış, PEF ön işleminin kuruma süresini $\% 22-27$ oranında azalttığ1 tespit edilmiştir (Liu vd., 2018b).

\section{PEF İşleminin Potansiyel Olumsuz Yönleri}

Günümüz itibarıyla PEF işleminin gıda güvenliği açısından riskli olduğuna dair bilgilere literatürde rastlanılmamaktadır veya sınırlı bilgi sunulmuştur. $\mathrm{Bu}$ konuda çalışmalar daha çok elektrot yüzeyindeki elektrokimyasal reaksiyonlar, serbest radikal oluşumu ve elektrotun korozyonu üzerinde odaklanmış durumdadır (Pakhomova vd., 2012; Zhang vd., 2011). Ortam özelliklerinin ve PEF parametre büyüklüklerinin bu reaksiyonların oluşumda rol oynadığ1 ifade edilmiştir (Morren vd., 2003). Örneğin, yüksek elektriksel iletkenlik ortamının suyun elektrolizini artırdığ1, ortamda klorürün bulunması halinde toksik klor bileşiğinin oluştuğu rapor edilmiştir (Hülsheger vd., 1981).

PEF'in kurutmada meydana getirebileceği olumsuzluklar hakkında, enzimatik aktivitedeki değişmeler daha ön planda ortaya çıkmaktadır. Sağlam dokuda hücre ve duvarlarında tutunan enzimler, elektroporasyon sonrasi substratlarina oksijen varlığında erişme imkanına kavuşmaktadır. $\mathrm{Bu}$ durum özellikle düşük sıcaklıktaki kurutmada, kuruma süresinin uzamasıyla daha da belirginleşmektedir. PEF ile muamele edilmiş bazı dokuların belirgin bir şekilde koyulaşması, polifenol oksidaz (PPO) enzimlerinin vakuolden salınan fenolik maddeler ile reaksiyonuna işaret etmektedir (Grimi vd., 2010; Janositz vd., 2011). Bundan başka, elektroporasyon sonrası diğer biyoaktif bileşikler ve renk maddeleri de enzimatik ve oksidatif bozulmalara açık hale gelmektedir. Yapılan bir çalışmada, havuç dokusuna uygulanan PEF işlemi, $\beta$-karoten zincirinin oksidasyonunu teşvik ederek toplam karotenoid içeriğin azalmasına neden olmuştur (Wiktor vd., 2015).

\section{SONUÇ}

Yapılan çalışmalara göre PEF uygulamasının, meyve ve sebze kurutma prosesinde bir ön işlem aşaması olarak kullanımı önemli avantajlar sağlamaktadır. Geleneksel kurutma yöntemlerinin aksine PEF, bitkisel dokulara elektrik alan uygulaması sonucu hücre zarının hasar1 ile kütle transferini artırıp, dokudan su çıkışını kolaylaştırmaktadır. $\mathrm{Bu}$ teknik, kurutma proseslerinde işlem süresini kısaltarak daha düşük enerji tüketimi sağlamaktadır. PEF aynı zamanda 1sıl olmayan bir teknoloji olduğu için 1sıya duyarlı hücre bileşenlerinin termal hasarını minimuma indirerek besinsel ve fiziksel kaliteyi iyileştirmeye yardımcı olmaktadır. Meyve ve sebzelerde PEF ön işlemi uygulaması, kurutma sonrası değerlendirilen antioksidan aktivite, vitamin, toplam fenolik madde ve toplam karotenoid içerik gibi birçok özelliğin daha az kaybı ile sonuçlanmıştır. PEF ön işleminin geleneksel yöntemlerin gıdalarda meydana getirdiği söz konusu kayıpları azaltmas1, yapılan farklı çalışmalarda ortaya konmuştur. Elektroporasyon olayı ile hücre zarında oluşan gözeneklerin, 55 ${ }^{\circ} \mathrm{C}$ 'nin üstündeki kurutma sıcaklıklarında hücre zarının erimesi sonucu önemi kalmamakla birlikte ek bir maliyete sebep olması da vurgulanması gereken ayrı bir konudur. Bu derlemede, çeşitli meyve ve sebzelere kurutma öncesi uygulanan PEF ön işleminin etkileri değerlendirildiğinde gıdanın renk özellikleri, tekstür ve besinsel içeriğin genelde korunduğu sonucuna varılmaktadır. Ürünlerde daha kaliteli kurutma sağlamak amacıyla PEF'in sağladığı optimum şartlar tespit edilmeli ve bu tekniğin kurutma proseslerinde kullanımının yaygınlaştırılması sağlanmalıdır.

\section{ÇIKAR ÇATIŞMASI BEYANI}

Yazarlar arasında çıkar çatışması bulunmamaktadir.

\section{YAZAR KATKILARI}

Makalenin derlenmesinde, yazilmasinda ve yayınlanmasında tüm yazarlar katkı sağlamışlardır.

\section{KAYNAKLAR}

Abbaspour-gilandeh, Y., Kaveh, M., Fatemi, H., Hernández-Hernández, J. L., Fuentes-Penna, A., Hernández-Hernández, M. (2020). Evaluation of 
the Changes in Thermal, Qualitative, and Antioxidant Properties of Terebinth ( Pistacia atlantica) Fruit under Different Drying Methods. Agronomy, 10(9), 1378. https://doi.org/10.3390/agronomy10091378

Alam, R., Lyng, J. G., Frontuto, D., Marra, F., Cinquanta, L. (2018). Effect of Pulsed Electric Field Pretreatment on Drying Kinetics, Colo, and Texture of Parsnip and Carrot. J Food Sci, 83(8), 2159-2166. https://doi.org/10.1111/17503841.14216

Aldemir, S. (2019). Vurgulu elektrik alanı kullanılarak nanenin esmerleştirilmesi ve yöntemin "Siyah nane çayı" ürünü geliştirilmesinde potansiyelinin incelenmesi. Erciyes Üniversitesi Fen Bilimleri Enstitüsü Gıda Mühendisliği Anabilim Dalı Yüksek Lisans Tezi, Kayseri, Türkiye, $92 \mathrm{~s}$.

Ando, Y., Mizutani, K., Wakatsuki, N. (2014). Electrical impedance analysis of potato tissues during drying. J Food Eng, 121(1), 24-31. https://doi.org/10.1016/j.jfoodeng.2013.08.008

Angersbach, A., Heinz, V., Knorr, D. (1999). Electrophysiological Model of Intact and Processed Plant Tissues: Cell Disintegration Criteria. Biotechnol Prog, 15(4), 753-762. https://doi.org/10.1021/bp990079f

Ariza-gracia, M. Á., Cabello, M. P., Cebrián, G., Calvo, B., Álvarez, I. (2020). Experimental and computational analysis of microbial inactivation in a solid by ohmic heating using pulsed electric fields. Innov Food Sci Emerg Technol, 65(2), 102440. https://doi.org/10.1016/j.ifset.2020.102440

Bozkir, H. (2020). Effects of hot air , vacuum infrared, and vacuum microwave dryers on the drying kinetics and quality characteristics of orange slices. J Food Process Eng, 43(10), 1-12. https://doi.org/10.1111/jfpe.13485

Chauhan, O. P., Sayanfar, S., Toepfl, S. (2018). Effect of pulsed electric field on texture and drying time of apple slices. J Food Sci Technol, 55(6), 2251-2258. https://doi.org/10.1007/s13197-

018-3142-x

Chen, Q., Li, Z., Bi, J., Zhou, L., Yi, J., Wu, X. (2017). Effect of hybrid drying methods on physicochemical , nutritional and antioxidant properties of dried black mulberry. LWT - Food Sci Technol, 80(2), 178-184. https://doi.org/ 10.1016/j.lwt.2017.02.017

Demiray, E., Tulek, Y. (2017). Degradation kinetics of $\beta$-carotene in carrot slices during convective drying. Int J Food Prop, 20(1), 151-156. https://doi.org/10.1080/10942912.2016.114746 0 Degradation

Dermesonlouoglou, E., Chalkia, A., Dimopoulos, G., Taoukis, P. S. (2018). Combined effect of pulsed electric field and osmotic dehydration pretreatments on mass transfer and quality of air dried goji berry. Innov Food Sci Emerg Technol, 49(39), 106-115. https://doi.org/10.1016/ j.ifset.2018.08.003

Dziki, D. (2020). Recent Trends in Pretreatment of Food before Freeze-Drying. Processes, 8(12), 1661. https://doi.org/https://doi.org/10.3390/ pr8121661

Emanuel, E., Dubrovin, I., Hanya, E., Pinhasi, G. A., Pogreb, R., Cahan, R. (2020). Eradication of Saccharomyces cerevisiae by Pulsed Electric Field Treatments. Microorganisms, $\quad$ 8(11), 1684. https://doi.org/https://doi.org/10.3390/micro organisms 8111684

Eshtiaghi, M. N., Knorr, D. (2002). High electric field pulse pretreatment: Potential for sugar beet processing. J Food Eng, 52(3), 265-272. https://doi.org/10.1016/S0260-8774(01)001145

Fauster, T., Giancaterino, M., Pittia, P., Jaeger, H. (2020). Effect of pulsed electric field pretreatment on shrinkage, rehydration capacity and texture of freeze-dried plant materials. LWT - Food Sci Technol, 121, 108937. https://doi.org/10.1016/ j.lwt.2019.108937

Fincan, M. (2015). Extractability of phenolics from spearmint treated with pulsed electric field. J Food Eng, 162, 31-37. https://doi.org/10.1016/j.jfoodeng.2015.04.004

Foster, K. R. (2008). Dielectric Properties of Tissues. In: Encyclopedia of Biomaterials and Biomedical Engineering (2nd ed.), W. Gary B. Gary 
(Eds.), CRC Press, Pennsylvania, USA, pp. 832842.

Gaylor, D. C., Prakah-Asante, K., Lee, R. C. (1988). Significance of Cell Size and Tissue Structure in Electrical Trauma. J Theor Biol, 133(2), 223-237. https://doi.org/10.1016/S00225193(88)80007-9

Ghafoor, K., Juhaimi, F. A., Özcan, M. M., Uslu, N., Babiker, E. E., Ahmed, I. A. M. (2020). Total phenolics, total carotenoids, individual phenolics and antioxidant activity of ginger (Zingiber officinale) rhizome as affected by drying methods. LWT - Food Sci Technol, 126, 109354. https://doi.org/10.1016/j.lwt.2020.109354

Grabowska, J., Marcin, K. (2021). Bioactive compounds, antioxidant activity, and sensory qualities of red-fleshed apples dried by different methods. LWT - Food Sci Technol, 136, 110302. https://doi.org/10.1016/j.lwt.2020.110302

Grimi, N., Mamouni, F., Lebovka, N., Vorobiev, E., Vaxelaire, J. (2010). Acoustic impulse response in apple tissues treated by pulsed electric field. Biosyst Eng, 105(2), 266-272. https://doi.org/10.1016/j.biosystemseng.2009.1 1.005

Guclu, G., Keser, D., Kelebek, H., Keskin, M., Sekerli, Y. E, Soysal, Y., Selli, S. (2021). Impact of production and drying methods on the volatile and phenolic characteristics of fresh and powdered sweet red peppers. Food Chem, 338, 128129. https://doi.org/10.1016/j.foodchem. 2020.128129

Hamid, H., Thakur, N. S., Thakur, A., Kumar, P. (2020). Effect of different drying modes on phenolics and antioxidant potential of different parts of wild pomegranate fruits. Sci Hortic, 274, 109656. https://doi.org/10.1016/j.scienta. 2020.109656

Huang, W., Feng, Z., Aila, R., Hou, Y., Carne, A., Bekhit, A. E.-D. A. (2019). Effect of pulsed electric fields (PEF) on physico-chemical properties, $\beta$-carotene and antioxidant activity of air-dried apricots. Food Chem, 291, 253-262. https://doi.org/10.1016/j.foodchem.2019.04.02 1
Hülsheger, H., Potel, J., Niemann, E. G. (1981). Killing of Bacteria with Electric Pulses of High Field Strength. Radiat Environ Biophys, 20(1), 5365. https://doi.org/10.1007/BF01323926

Izli, N., Izli, G., Taskın, O. (2017a). Drying kinetics, colour, total phenolic content and antioxidant capacity properties of kiwi dried by different methods. J Food Meas Charact, 11(1), 6474. https://doi.org/10.1007/s11694-016-9372-6

Izli, N., Izli, G., Taskın, O. (2017b). Influence of different drying techniques on drying parameters of mango. Food Sci Technol, 37(4), 604-612. https://doi.org/10.1590/1678-457X.28316

Janositz, A., Noack, A.-K., Knorr, D. (2011). Pulsed electric fields and their impact on the diffusion characteristics of potato slices. LWT Food Sci Technol, 44(9), 1939-1945. https://doi.org/10.1016/j.lwt.2011.04.006

Kakı, H. İ., Balkan, B., Akar, M., Font, A., Güler, F. K., Kalenderli, Ö. (2014). Darbeli Elektrik Alan Uygulamasının Sıvı Gıdaların Pastörizasyonunda Kullanımı. Eleco 2014 Elektrik-ElektronikBilgisayar ve Biyomedikal Mühendisliği Sempozyumu, 27 - 29 Kasim 2014, Bursa, Türkiye, s. 230-234.

Kandušer, M., Miklavčič, D. (2008). Electroporation in Biological Cell and Tissue: An Overview. In: Electrotechnologies for Extraction from Food Plants and Biomaterials, E. Vorobiev N. I. Lebovka (Eds.), Springer, New York, NY, pp.137.

Kempkes, M., Simpson, R. (2018). Pulsed Electric Field ( PEF) Processing of Fruit and Vegetables. IEEE International Power Modulator and High Voltage Conference (IPMHVC), 3-7 June 2018, Jackson, WY, USA, pp. 499-503.

Kerr, W. L., Varner, A. (2020). Chemical and physical properties of vacuum-dried red beetroot (Beta vulgaris) powders compared to other drying methods. Dry Technol, 38(9), 1165-1174. https://doi.org/10.1080/07373937.2019.161957 3

Khan, M. I. H., Nagy, S. A., Karim, M. A. (2018). Transport of cellular water during drying: An understanding of cell rupturing mechanism in 
apple tissue. Food Res Int, 105, 772-781. https://doi.org/10.1016/j.foodres.2017.12.010

Knorr, D., Angersbach, A. (1998). Impact of high-intensity electric field pulses on plant membrane permeabilization. Trends Food Sci Technol, 9(5), 185-191. https://doi.org/10.1016/S0924-2244(98)000405

Koç, G. Ç. (2020). The effect of different drying techniques and microwave finish drying on the powder properties of the red pepper powder ( Capsicum annum L .). J Food Sci Technol, 57(12), 4576-4587. https://doi.org/10.1007/s13197020-04496-1

Kotnik, T., Rems, L., Tarek, M., Miklavčič, D. (2019). Membrane Electroporation and Electropermeabilization: Mechanisms and Models. Annu Rev Biophys, 48, 63-91. https://doi.org/https://doi.org/10.1146/annur ev-biophys-052118- 115451

Lammerskitten, A., Shorstkii, I., Parniakov, O., Mykhailyk, V., Toepfl, S., Rybak, K., Dadan, M., Nowacka, M., Wiktor, A. (2020). The effect of different methods of mango drying assisted by a pulsed electric field on chemical and physical properties. J Food Process Preserv, 44(12), 1-9. https://doi.org/10.1111/jfpp.14973

Lammerskitten, A., Wiktor, A., Mykhailyk, V., Samborska, K., Gondek, E., Witrowa-rajchert, D., Toepfl, S., Parniakov, O. (2020). Pulsed electric field pre-treatment improves microstructure and crunchiness of freeze-dried plant materials: Case of strawberry. LWT - Food Sci Technol, 134, 1-8. https://doi.org/10.1016/j.lwt.2020.110266

Lammerskitten, A., Wiktor, A., Siemer, C., Toepfl, S., Mykhailyk, V., Gondek, E., Rybak, K., Witrowa-rajchert, D., Parniakov, O. (2019). The effects of pulsed electric fields on the quality parameters of freeze-dried apples. J Food Eng, 252, 36-43.

https://doi.org/10.1016/j.jfoodeng.2019.02.006

Lebovka, N. I., Bazhal, M. I., Vorobiev, E. (2002). Estimation of characteristic damage time of food materials in pulsed-electric fields. J Food Eng,
54(4), 337-346. https://doi.org/10.1016/S02608774(01)00220-5

Leiton-Ramírez, Y. M., Ayala-Aponte, A., OchoaMartínez, C. I. (2020). Physicochemical Properties of Guava Snacks as Affected by Drying Technology. Processes, 8(1), 106. https://doi.org/10.3390/pr8010106

Lewicki, P. P., Pawlak, G. (2003). Effect of Drying on Microstructure of Plant Tissue. Dry Technol, 21(4), 657-683. https://doi.org/10.1081/ DRT-120019057

Liu, C., Grimi, N., Lebovka, N., Vorobiev, E. (2018a). Effects of preliminary treatment by pulsed electric fields and convective air-drying on characteristics of fried potato. Innov Food Sci Emerg Technol, 47(2), 454-460. https://doi.org/10.1016/j.ifset.2018.04.011

Liu, C., Grimi, N., Lebovka, N., Vorobiev, E. (2018b). Effects of pulsed electric fields treatment on vacuum drying of potato tissue. LWT - Food Sci Technol, 95, 289-294. https://doi.org/ 10.1016/j.lwt.2018.04.090

Liu, C., Vorobiev, E., Grimi, N., Pirozzi, A., Ferrari, G. (2020). Effects of Pulsed Electric Fields on Vacuum Drying and Quality Characteristics of Dried Carrot. Food Bioproc Technol, 13(1), 45-52. https://doi.org/10.1007/ s11947-019-02364-1

Liu, Y., Duan, Z., Sabadash, S. (2020). Effect of hot air drying temperatures on drying characteristics and physicochemical properties of beetroot ( Beta vulgaris) slices. IOP Conf Ser: Earth Environ Sci, 615, 012099. https://doi.org/ 10.1088/1755-1315/615/1/012099

Llavata, B., García-Pérez, J. V., Simal, S., Cárcel, J. A. (2019). Innovative pre-treatments to enhance food drying: a current review. J Food Sci, 35, 20-26. https://doi.org/10.1016/j.cofs. 2019.12.001

Maor, E., Sugrue, A., Witt, C., Vaidya, V. R., Desimone, C. V, Asirvatham, S. J., Kapa, S. (2021). Pulsed electric fields for cardiac ablation and beyond: A state-of-the-art review. Heart Rhythm, 16(7), 1112-1120. https://doi.org/ 10.1016/j.hrthm.2019.01.012 
Mierzwa, D., Pawłowski, A. (2017). Convective drying of potatoes assisted by microwave and infrared radiation-process kinetics and quality aspects. J Food Nutr Res, 56(4), 351-361.

Morren, J., Roodenburg, B., de Haan, S. W. H. (2003). Electrochemical reactions and electrode corrosion in pulsed electric field (PEF) treatment chambers. Innov Food Sci Emerg Technol, 4(3), 285$295 . \quad$ https://doi.org/10.1016/S14668564(03)00041-9

Mousakhani-ganjeh, A., Amiri, A., Nasrollahzadeh, F., Wiktor, A., Nilghaz, A., Pratap-Singh, A., Khaneghah, M. A. (2021). Electro-based technologies in food drying - A comprehensive review. LWT - Food Sci Technol, 145, $111315 . \quad$ https://doi.org/10.1016/ j.lwt.2021.111315

Nawirska-Olszańska, A., Stępień, B., Biesiada, A., Kolniak-Ostek, J., Oziembłowski, M. (2017). Rheological, Chemical and Physical Characteristics of Golden Berry ( Physalis peruviana L.) after Convective and Microwave Drying. Foods, 6(8), 60. https://doi.org/10.3390/ foods 6080060

Nemzer, B., Vargas, L., Xia, X., Sintara, M., Feng, H. (2018). Phytochemical and physical properties of blueberries, tart cherries, strawberries, and cranberries as affected by different drying methods. Food Chem, 262(4), 242-250. https://doi.org/10.1016/j.foodchem.2018.04.04 7

Neri, L., Giancaterino, M., Rocchi, R., Tylewicz, U., Valbonetti, L., Faieta, M., Pittia, P. (2021). Pulsed electric fields ( PEF) as hot air drying pretreatment: Effect on quality and functional properties of saffron (Crocus sativus L .). Innov Food Sci Emerg Technol, 67, 102592. https://doi.org/10.1016/j.ifset.2020.102592

Onwude, D. I., Hashim, N., Janius, R., Abdan, K., Chen, G., Oladejo, A. O. (2017). Non-thermal hybrid drying of fruits and vegetables: A review of current technologies. Innov Food Sci Emerg Technol, 43, 223-238. https://doi.org/10.1016/ j.ifset.2017.08.010

Ostermeier, R, Giersemehl, P., Siemer, C., Töpfl, S., Jäger, H. (2018). Influence of pulsed electric field (PEF) pre-treatment on the convective drying kinetics of onions. J Food Eng, 237, 110$117 . \quad$ https://doi.org/10.1016/j.jfoodeng. 2018.05.010

Ostermeier, R., Parniakov, O., Töpfl, S., Jäger, H. (2020). Applicability of Pulsed Electric Field (PEF) Pre-Treatment for a Convective Two-Step Drying Process. Foods, 9(4), 512. https://doi.org/https://doi.org/10.3390/foods 9040512

Pakhomova, O. N., Khorokhorina, V. A., Bowman, A. M., Rodaitė-Riševičienė, R., Saulis, G., Xiao, S., Pakhomov, Andrei, G. (2012). Oxidative effects of nanosecond pulsed electric field exposure in cells and cell-free media. Arch Biochem Biophys, 527(1), 55-64. https://doi.org/10.1016/j.abb.2012.08.004

Radojčin, M., Pavkov, I., Kovačević, D. B., Putnik, P., Wiktor, A., Stamenković, Z., Kešelj, K., Gere, A. (2021). Effect of Selected Drying Methods and Emerging Drying Intensification Technologies on the Quality of Dried Fruit: A Review. $\quad$ Processes, $\quad 9(1), \quad 132$. https://doi.org/https://doi.org/10.3390/pr901 0132

Rahaman, A., Siddeeg, A., Manzoor, M. F., Zeng, X.-A., Ali, S., Baloch, Z., Li, J., Wen, Q.-H. (2019). Impact of pulsed electric field treatment on drying kinetics, mass transfer, colour parameters and microstructure of plum. J Food S $i$ Technol, 56(5), 2670-2678. https://doi.org/ 10.1007/s13197-019-03755-0

Ramaswamy, R., Ramachandran, R. P. (2017). Electric Field Analysis of Different Compact Electrodes for Pulsed Electric Field Applications in Liquid Food. IEEE International Power Modulator and High Voltage Conference (IPMHVC), 6-9 July 2016, San Francisco, CA, USA, pp. 160-165.

Rols, M., Teissie, J. (1990). Modulation of Electrically Induced Permeabilization and Fusion of Chinese Hamster Ovary Cells by Osmotic Pressure. Biochemistry, 29(19), 4561-4567. https://doi.org/10.1021/bi00471a009

Rubin, A. E., Usta, O. B., Schloss, R., Yarmush, M., Golberg, A. (2018). Selective Inactivation of 
Pseudomonas aeruginosa and Staphylococcus epidermidis with Pulsed Electric Fields and Antibiotics. $A d v$ Wound Care, 8(4), 136-148. https://doi.org/ 10.1089/wound.2018.0819

Rybak, K., Samborska, K., Jedlinska, A., Parniakov, O., Nowacka, M., Witrowa-rajchert, D., Wiktor, A. (2020). The impact of pulsed electric field pretreatment of bell pepper on the selected properties of spray dried juice. Innov Food Sci Emerg Technol, 65, 1-8. https://doi.org/ 10.1016/j.ifset.2020.102446

Sagar, V. R., Kumar, P. S. (2010). Recent advances in drying and dehydration of fruits and vegetables: a review. J Food Sci Technol, 47(1), 15-26. https://doi.org/10.1007/s13197-010-0010-8

Sehrawat, R., Nema, P. K., Kaur, B. P. (2018). Quality evaluation and drying characteristics of mango cubes dried using low-pressure superheated steam, vacuum and hot air drying methods. LWT - Food Sci Technol, 92, 548-555. https://doi.org/10.1016/j.lwt.2018.03.012

Shabbir, M. A., Ahmed, H., Maan, A. A., Rehman, A., Afraz, M. T., Iqbal, M. W., Khan, I. M., Amır, R. M., Ashraf, W., Khan, M. R., Aadıl, R. M. (2020). Effect of non-thermal processing techniques on pathogenic and spoilage microorganisms of milk and milk products. Food Sci Technol, 41(2), 279-294. https://doi.org/ $10.1590 /$ fst.05820

Silve, A., Leray, I., Poignard, C., Mir, L. M. (2016). Impact of external medium conductivity on cell membrane electropermeabilization by microsecond and nanosecond electric pulses. $S c i$ Rep, 6(1), 1-15. https://doi.org/10.1038/ srep19957

Smith, J. C., Biasi, W. V, Holstege, D., Mitcham, E. J. (2018). Effect of Passive Drying on Ascorbic Acid , $\alpha$-Tocopherol, and $\beta$-Carotene in Tomato and Mango. $J$ Food Sci, 83(5), 1412-1421. https://doi.org/10.1111/1750-3841.14118

Soliva-fortuny, R., Balasa, A., Knorr, D., MartinBelloso, O. (2009). Effects of pulsed electric fields on bioactive compounds in foods: a review. Trends Food Sci Technol, 20(11-12), 544-556. https://doi.org/10.1016/j.tifs.2009.07.003
Szadzińska, J., Łechtańska, J., Kowalski, S. J., Stasiak, M. (2017). The effect of high power airborne ultrasound and microwaves on convective drying effectiveness and quality of green pepper. Ultrason Sonochem, 34, 531-539. https://doi.org/10.1016/j.ultsonch.2016.06.030

Takougnadi, E., Boroze, T.-E. T., Azouma, O. Y. (2020). Effects of drying conditions on energy consumption and the nutritional and organoleptic quality of dried bananas. J Food Eng, 268(1), 1-9. https://doi.org/10.1016/j.jfoodeng.2019.109747

Telfser, A., Galindo, F. G. (2019). Effect of reversible permeabilization in combination with different drying methods on the structure and sensorial quality of dried basil (Ocimum basilicum L.) leaves. LWT - Food Sci Technol, 99(11), 148155. https://doi.org/10.1016/j.lwt.2018.09.062

Tylewicz, U., Oliveira, G., Alminger, M., Nohynek, L., Rosa, M. D., Romani, S. (2020). Antioxidant and antimicrobial properties of organic fruits subjected to PEF- assisted osmotic dehydration. Innov Food Sci Emerg Technol, 62, 102341.

https://doi.org/10.1016/j.ifset.2020.102341

Wang, X., Gao, Y., Zhao, Y., Li, X., Fan, J., Wang, L. (2020). Effect of different drying methods on the quality and microstructure of fresh jujube crisp slices. J Food Process Preserv, 45(2), 1-9. https://doi.org/10.1111/jfpp.15162

Wiktor, A., Sledz, M., Nowacka, M., Rybak, K., Chudoba, T., Lojkowski, W., Witrowa-rajchert, D. (2015). The impact of pulsed electric field treatment on selected bioactive compound content and color of plant tissue. Innov Food Sci Emerg Technol, 30, 69-78. https://doi.org/10.1016/j.ifset.2015.04.004

Wojdyło, A., Lech, K., Nowicka, P., Hernandez, F., Figiel, A., Carbonell-Barrachina, A. A. (2019). Influence of Different Drying Techniques on Phenolic Compounds, Antioxidant Capacity and Colour of Ziriphus jujube Mill. Fruits. Molecules, 24(13), 2361. https://doi.org/10.3390/ molecules 24132361

Wu, X., Wang, C., Guo, Y. (2020). Effects of the high-pulsed electric field pretreatment on the mechanical properties of fruits and vegetables. $J$ 
Food Eng, 274, 109837. https://doi.org/10.1016/j.jfoodeng.2019.109837

Wu, Y., Zhang, D. (2019). Pulsed electric field enhanced freeze-drying of apple tissue. Czech J Food Sci, 37(6), 432-438. https://doi.org/10.17221/230/2018-CJFS

Xu, X., Chen, Y., Zhang, R., Miao, X., Chen, X. (2018). Activation of Anti-tumor Immune Response by Ablation of HCC with Nanosecond Pulsed Electric Field. J Clin Transl Hepatol, 6(1), 85-88.

JCTH.2017.00042

Xu, Y., Xiao, Y., Lagnika, C., Song, J., Li, D., Liu, C., Jiang, N., Zhang, M., Duan, X. (2020). A comparative study of drying methods on physical characteristics, nutritional properties and antioxidant capacity of broccoli. Dry Technol, 38(10), 1378-1388. https://doi.org/10.1080/ 07373937.2019 .1656642

Yamada, T., Yamakage, K., Takahashi, K., Takaki, K., Orikasa, T., Aoki, H., Kamagata, J. (2020). Influence of Drying Rate on Hot Air Drying Processing of Fresh Foods Using Pulsed Electric Field. IEEJ Trans Elec Electron Eng, 15(7), 11231125. https://doi.org/10.1002/tee.23158

Yarmush, M. L., Golberg, A., Kotnik, T., Serša, G., Miklavčič, D. (2014). Electroporation-Based Technologies for Medicine: Principles, Applications, and Challenges. Annu Rev Biomed Eng, 16, 295-320. https://doi.org/10.1146/ annurev-bioeng-071813-104622

Yu, Y., Jin, T. Z., Fan, X., Wu, J. (2018). Biochemical degradation and physical migration of polyphenolic compounds in osmotic dehydrated blueberries with pulsed electric field and thermal pretreatments. Food Chem, 15(239), 1219-1225. j.foodchem.2017.07.071

Yu, Y., Jin, T. Z., Xiao, G. (2017). Effects of pulsed electric fields pretreatment and drying method on drying characteristics and nutritive quality of blueberries. J Food Process Preserv, 41(6), 1-9. https://doi.org/10.1111/jfpp.13303

Zhang, S., Yang, R., Zhao, W., Liang, Q., Zhang, Z. (2011). The first ESR observation of radical species generated under pulsed electric fields processing. LWT - Food Sci Technol, 44(4), 12331235. https://doi.org/10.1016/j.lwt.2010.11.016

Zhang, Z., Zhang, B., Yang, R., Zhao, W. (2020). Recent Developments in the Preservation of Raw Fresh Food by Pulsed Electric Field. Food Rev Int, 00(00), 1-19. https://doi.org/10.1080/ 87559129.2020 .1860083

Zhao, J., Chen, S., Zhu, L., Zhang, L., Liu, J., Xu, D., Tian, G., Jiang, T. (2021). Antitumor Effect and Immune Response of Nanosecond Pulsed Electric Fields in Pancreatic Cancer. Front Oncol, 10, 621092. https://doi.org/10.3389/ fonc.2020.621092

Zimmermann, U. (1986). Electrical Breakdown, Electropermeabilization and Electrofusion. Rev Physiol Biochem Pharmacol, 105, 176-250. https://doi.org/10.1007/BFb0034499 